\title{
Perception of Adult and Non-Formal Education Learners on the Problems and Prospects of Globalisation and Entrepreneurship
}

\author{
Uju A. Nwobi ${ }^{1}$, Charity Chinelo Okide ${ }^{1}$, Felicia Ukamaka Iremeka ${ }^{2}$, \\ Chioma Osilike $^{1}$ and Felicia O. Mbagwu ${ }^{1 *}$ \\ ${ }^{1}$ Department of Adult Education \& Extra-Mural Studies, \\ University of Nigeria Nsukka \\ ${ }^{2}$ Department of Educational Foundations, University of Nigeria Nsukka \\ *mbagwu.felicia@gmail.com
}

\begin{abstract}
In this work, the researchers tried to $x$-ray the perceptions of adult and non-formal education on the problems and prospects of globalisation and entrepreneurship in the 21 st century. Four research questions guided questions guided the study. The population for the study was 360 adult and non-formal learners in Nsukka local government area of Enugu state. The sample for the study included all the 360 learners because of their manageable number. Simple random sampling technique was used to select the subjects for the study. The instrument used was a well-structured and guided subject for the study. The instrument used was a well-structured and guided questionnaire for analysing the research questions. The following major findings emerged: Globalisation and Entrepreneurship had positive impacts on Adult and Non-formal learners by ensuring that the economy is socially inclusive and that entrepreneurial skills promote the learners. Major recommendations were also stated in the study.
\end{abstract}

Keywords: Perception, Adult, Non-formal education, Learners, Globalization, Entrepreneurship

\section{Introduction}

In the context of changing production systems, there is increasing recognition of the pivotal role of both education and training of adult and non-formal learners which are not only instrumental to economic growth but are also a human right. This was explicitly mentioned in the 1948 Universal Declaration of Human Rights and many international and regional agreements and national constitutions. Training and skills development are included in the standard definition of 'basic education for all' agreed in the Jomtien Conference in 1990 which covered all the skills and knowledge that people need if they need to lead a decent life. This basic learning needs not to include only early childhood education and primary schooling, but adult and non-formal education, vocational and other training for youths and adults to provide basic life and employment skills (Johnstone and William, 1998).

Entrepreneurship can be seen as the process of uncovering and developing an opportunity to create value through innovation (National Conference on Education, 2003). Entrepreneurship and entrepreneurial skills are core components to building socially inclusive and highly participatory economies in an increasingly global and competitive world. As such, entrepreneurship cuts across all sectors of the society and not just the economy. It is clear that the last decades of the 20th century saw the emergence of globalisation, flexible forms of capital accumulation and consumerism as key descriptions

Received (March 16, 2018), Review Result (June 5, 2018), Accepted (June 6, 2018)

* Corresponding Author 
of economic life. Entrepreneurship education centre as obtained in the Polytechnics can be described as a centre usually in an educational environment that engages the coordination and delivery of entrepreneurship training and services to members of the community. The entrepreneurship education centre does not only provide services to the Polytechnic but also to the host community where it operates. The centre offers the following services: Entrepreneurship courses, connection to business outfit and alumni, technology, commercialization, internship, venture capital, student organization, business plan competition and guest speakers, workshops, seminars, conferences, general advice and counseling (NBTE, 2007).

The goal of entrepreneurship education centres is to promote entrepreneurship programme and education with the aim of instilling the entrepreneurial mind-set in the students with a view of reducing poverty and graduate unemployment through the commercialization of innovations and inventions for the development of sustainable micro and medium enterprises that can ensure overall economic growth and development (NBTE, 2014). The specific goals of the centre include: creating and promoting entrepreneurial awareness and opportunities, imparting entrepreneurial skills in students and staff of the tertiary institutions; making employers of labour in Nigerian graduate.; stimulating the development and growth of entrepreneurship in Nigeria; creating career development for economic transformation. (NBTE, 2014). The entrepreneurship education centres will provide entrepreneurship education to students before graduation from school. Entrepreneurship is aimed at encouraging and developing skills which will lead to economic activities and poverty reduction. (Shuaibu, 2005). Shuaibu further explained that entrepreneurship is the capacity for creativity, innovation, investment and expansion in new market products and techniques. Entrepreneurship is defined as the study where a person coordinates, integrates controls and harmonizes resources to achieve organizational objectives (TETFUND, 2015). Entrepreneurship education as defined by the consortium for entrepreneurship (CEE, 2005), is a form of education that seeks to prepare people especially youth to be responsible enterprising, individual, who become entrepreneur and entrepreneurial thinkers and contribute to economic development and sustainable communities. It helps to exploit and launch business opportunities with the aim of creating jobs, and maximizing wealth (Kiadese, 2008). Entrepreneurship education develops and stimulates entrepreneurial process by providing the entire necessary tool for starting up ventures (Fasua, 2006). Nafukho (2005) is of the opinion that entrepreneurship education is catalyst for business formation; it teaches students how to start and run their business; play the stock market role and balance personal life. According to Okon (1990), the basic objectives of entrepreneurship education is to develop entrepreneurship aspiration and culture with purpose of fostering economic growth through creation of new firms.

While the term globalisation is being contested for, one can easily define it as "the closer integration of the countries and the people of the world, which has been brought about by the enormous reduction of the costs of transportation and communication and the breaking down of artificial barriers to the flow of goods, services, capital and knowledge for people across borders (Stiglitz, 2002:9). One of the outcomes of globalisation is that a predominantly social demand is now becoming even greater than before: an impressive demand for capability that consists of autonomy, adaptability to innovation, the ability to work in groups, acceptance of responsibility, competence based upon attitudes that guarantee the maintenance and renewal of skills (Lozono, 2002:145). Consequently, a society that needs to survive on knowledge creation and innovation in the real sense of it, does not simply need institutionalised periods of instruction that is, compulsory schooling but has to foster on adult and non-formal education to raise the general skill level of the working population. Education has always been subject to external pressures that seek to subordinate its practice and goals to vested interest. The implications of corporate globalisation for the practice of adult and non-formal education are far-reaching. It will 
result to the total dependency of the system and will affect every aspect of adult and nonformal education. Under this role of advocacy agenda, education is open to those who can pay fully; those who cannot afford to pay will have to drop out entirely. Teaching in adult and non-formal educational system under this agenda will be done by an academic staff (Cruickshank, 1993:181).

Adult and non-formal learning under the corporate globalisation and entrepreneurship agenda would become an output to offset the input and costs incurred already (Johnstone et al., 1998:5), and must compete with learning in the private sector, which is cost effective and market responsive in a society like outs. Learning for earning will dominate including proficiency-based learning for certification which is already a big problem in our society, Nigeria (Denning, 1997:23). Under this agenda, lifelong learning becomes lifelong adaptation to the needs of the new global economy (Welton, 1997:33). Outcomes for adults and non-formal education under the corporate globalisation and entrepreneurship agenda involve quantification and ownership. The overriding philosophy is the counting of anything that can be counted. How much money? How many learners? (Cruickshank, 1993:180). The only knowledge that is recognised is the knowledge that can be commoditized and privately conceived purposes (Nelson, 1998:122). And following Frieres' banking model (1996:53) of education, knowledge will be deposited in the heads of learners who can afford to pay for it. All in all, adult and non-formal education under the corporate globalisation and entrepreneurship agenda is reduced to technology that can be bought in the marketplace by the highest bidder (Cunningham in Cruickshank 1993:173). It is on this premise that the researchers want to investigate the perception of Adult and non-formal learners towards globalisation and entrepreneurship in the 21 st century.

The massive increase in adult and non-formal learners' enrolment was, however, less a consequence of government policy than the impact of government policy than the impact of changing perceptions of the labour market. The surge in the number of learners occurred because it became clear to a large number of people that not having a degree disadvantaged them in the labour market. At a certain point in what has been a steady, slow expansion, a large number of people started to feel that they had better get degrees because not doing so will be such a bad move. The first wave set off another and so on (Baumol, 2002). As Stewart demonstrated, there is a fundamental problem with the way government policies are applied to the adult and non-formal education in particular based on their distinctive purposes, conditions and tasks (Stewart 1992:27).

Innovation and economic growth depend largely on being able to produce leaders with the skills and attitudes to be entrepreneurial in their professional lives, whether by creating their own companies or innovating in larger organisations. It is imperative to develop entrepreneurial skills, attitudes and behaviours in adult and non-formal learners reaching across all ages as part of a lifelong learning process. At the same time, there is no 'one size fits all' solution for entrepreneurship education. The challenges and opportunities for entrepreneurship vary dramatically in different parts of the world as well as for different parts of the world as well as for different segments of the educational journey (Wilson, 2009). Adult and non-formal learners often have to alter their learning strategies according to the cultural background of the learning system in the country. This learning system has been largely altered by the power of globalisation through increasing education curriculum brought in from the developed world. It on this premise that the investigated the perceptions of Adult and Non-Formal learners towards the problems and prospects of Globalisation and Entrepreneurship in this 21st century.

\subsection{Theoretical and Literature Review}

One theory considered in this article is the Social Structure Theory which was propounded by Kunkel in 1965. The Social Structure Theory postulated that entrepreneurial behaviour is a function of the surrounding social structure of the 
entrepreneur. According to this theory, the type of social values that exist in the society accounts for the types of entrepreneurial skill. This theory is based on experimental psychology, which identifies sociological variables as the determinants of entrepreneurship supply. Another theory discussed in this study is the Achievement motivation theory which was put forward by McClelland in 1961. McClelland postulated that the drive for achievement, responsibility and independence are factors that motivates entrepreneurial activities not just competence. Having identified achievement motivation as the main driving force in the development of entrepreneurship, the theorist suggested motivation training programme as policy measure to make entrepreneurs become willing and eager to exploit new opportunities in the workplace. Also, this study considered the sociological theory of entrepreneurship which was propounded by Young in 1971 and postulates that intergroup relationship affects entrepreneurial activity when two conditions coincide. The theorist notes that the groups will work harder to be successful entrepreneurs in those conditions that they are being denied. The theorist opined that the creation of supporting institution in society can be determinant of entrepreneurship. The social construct theory which was propounded by Cochram in 1968 based on social construct was considered as well. The theorist argues that the environment in which the individual is brought up determines to a large extent the entrepreneurial urge in an individual. The profounder identifies cultural values, role expectations and social sanctions as factors affecting entrepreneurship. Finally, the study considered the scientific management theory which was propounded by Fredrick in 1915. The scientific management theory seeks to examine scientifically the best approach to increase productivity and efficiency of workers. According to this theory, the problem of productivity and efficiency is due to ignorance of the management and workers. The proponent advocates for application of science to the study of work and management in order to discover the best technique of performing a job, and the most efficient method of controlling workers.

Regarding related empirical studies, Jibodu and Phiri (1990) conducted a study in technical institutions in Tanzania and Sierra-leon. They investigated the adequacy of college curricula for providing needed skills and attitudes relevant to job situations. A structured interview technique was used to elicit responses from 21 employers of labour and 78 graduates of technical institutes in the two countries. Some of the findings that emanated from data analysis were that: lack of practical skills and entry point in electrical and mechanical trades, graduates lacked management and workshop planning skills; graduates lacked technical competence and graduates needed practical skills in heat treatment, production management, and skilled workmanship. Also, Uzoagulu (1993) investigated equipment management styles in technical schools (the foundation for skills acquisition through productions/service unit's activities). Questionnaire survey was administered to 42 heads of technical units in post primary institutions, consisting of items to determine the condition of tools and equipment in schools and identifying the management styles used in schools for tools and equipment. Some of the findings revealed by the data analysis included: in three years a total of 207 tools and equipment were lost in 12 technical departments of the institutions used in the study, a total of 211 equipment were rendered unusable in the various technical departments. Others were out of 95 personnel in the departments, 37 representing 38.94 percent participated in the management of tools and equipment, the schools sampled did not carry out any maintenance service on introductory technology equipment, and some of this equipment were non functional. Anaele (1997) carried out a study to identify entrepreneurial competencies need by technical college students for self employment. The study was a survey type that covered five Eastern States which include: Abia, Anambra, Ebonyi, Enugu and Imo State. Entrepreneurial Competencies questionnaire ECQ) was used for data collection. The population comprised of 5.4 entrepreneurs in technical occupations and 388 technical teachers in the states covered by the study. No sampling was involved. 
Mean scores, t-test and analysis of variance (ANOVA) were used for data analysis. The findings revealed that 90 entrepreneurial competencies needed by technical college students for self-employment. Factors that could hinder as well as techniques that could enhance teaching and learning entrepreneurial competencies were also identified. Also, Alio (2006) carried out a study on strategies for improving the theoretical competencies, technical skills and management competencies of electronics craftsmen in the informal sector of the economy. Seven research questions were developed and answered by the study and five null hypotheses were formulated and tested at 0.05 level of significance. The population for the study consisted of 850 craftsmen operating in the formal sector of the economy of Enugu State. Fifty percent of the population was sampled. One hundred and eighteen - item questionnaire was used as instrument for data collection. Three experts validated the instrument and Cronbach alpha reliability coefficient method was used to determine the internal consistency of the instrument. The instrument yielded a reliability coefficient of 0.98 . Frequency counts, percentages, mean and standard deviation were used to answer the seven research questions, while the five null hypotheses were tested using analysis of variance (ANOVA) and t-test at 0.05 level of significance. The major findings of the study was that the electronics craftsmen in the informal sector of the economy posed either first school leaving certificate lower number of years of school. Approximately, seventy percent of the craftsmen who operates in the informal sector of the economy have never worked in any industry. Most of the craftsmen of the age range of between 21-30 and 31-40 years. The craftsmen in the informal sector of the economy posses a high level of theoretical competencies, technical skills and management competencies required of craftsmen for efficient operation in their workshops/ establishment.

Furthermore, Kaidese (2009) investigated decision making habit and risk taking behavior as correlates of entrepreneurship aspiration using descriptive designed correlation type. A total of 250 final year students selected through purposive sampling technique from four institutions in Ogun State participated in the study. Findings from the study revealed a relative contribution of two independent measures to the variance of the entrepreneurial aspiration of students. The two variables (decision making and risk raking behavior) jointly predicted entrepreneurship aspiration of students. Enete, Amusa, and Eze (2009) investigated the entrepreneurial competency required by students of school of agriculture in South Western Nigeria for processing cocoyam into flours and chips for employment on graduation. The study made use of survey research design. The population of the study was 440 made up of 200 instructors in schools of Agriculture in Ondo and Oyo States respectively and 240 food processors in the two states. The sample of the study was 56 . This is made up of 26 instructors purposively sampled from the departments of crop science and Home Economics in the two schools and 30 food processors from the two states. The study revealed that all the 33 entrepreneurial competencies indentified in Cocoyam processing into flour and chips were required by the students. It was also found out from the hypotheses tested that there is no significant difference in the mean responses of instructors and food processors in the thirty three (33) entrepreneurial competency items. Olaitan, Eze, and Ogbonnaya (2009) conducted a study on identifying entrepreneurial competencies required by secondary school graduates for entering into oil palm processing enterprise in South Eastern States of Nigeria. The study was carried out in South Eastern States of Nigeria. Survey and function of industry design were adopted for the study. Sample for the study was 459 made up of 277 teachers of agricultural science and 182 oil palm processors. The result of the study revealed that 11 competencies in planning, 16 competencies in palm oil processing and 18 competencies in marketing of palm oil were required for success in palm oil processing enterprise.

In a related effort, Obiyai and Ezubo (2011) carried a study to develop an entrepreneurship skill training module for enhancing fish farmers in fish breeding at hatching occupation. The study was carried out in Bayelsa State. The design for the study 
was instrumentation. The sample of 40 respondents consisting of 30 Agricultural Extension officers and 10 University Lecturers of the department of fisheries technology were selected through purposive sampling technique. The instrument for data collection was a structured questionnaire using four point rating scale. The research questions were answered using mean standard deviation. The result revealed that 42 entrepreneurship skills were needed for the development of the training module for fish breeding and hatching. Oko (2011) conducted a study on the entrepreneurial competencies required by technicians for success in small scale automobile maintenance industry in Benue State. Survey design was used for the study. Six research questions were developed and six null hypotheses were also formulated and tested at the probability of 0.05 level of significance. A structured questionnaire was developed from the reviewed literature and used for the study. The questionnaire were used for collecting data from 306 respondents made up of 100 entrepreneurs and 206 employees drawn from 100 registered small scale automobile maintenance industries in the three senatorial zones of Benue State. The data collected were analyzed using the mean and standard deviation to answer the research questions and the t-test was used for testing the null hypotheses. Based on the data analyzed, it was found out from the study that the following competencies were required for success in automobile maintenance industry in Benue State. The study further revealed that technicians require 24 personality competencies 27 managerial competencies 14 marketing competencies, 15 accounting and book keeping competencies and 13 human relation competencies. The study also revealed 10 strategies for equipping the entrepreneurs with the competencies for success in small scale automobile maintenance industry.

Furthermore, Adam (2011) conducted a study on challenges facing technical institution graduates in practical skills acquisition in the upper east region of Ghana. The study adopted a survey research design in carrying out the investigation. The study area was the upper east region and centred on the two municipalities where the two technical institutes are situated. The upper east region has a number of post-basic educational establishments. These include: One polytechnic three nursing institutions, two teacher training institutions, 26 state owned senior high schools and two public technical institutes. The population for the study was 86 teachers, 350 graduates from the technical institutes and a student's population of 482 . All the 86 teachers, 150 technical institutes graduate and 241 students in all the programme areas of the two technical institutes in the regions (Bawku Technical Institutes and the Bolgatauga technical institute were selected for the selection of the actual sample proportional purposive and sample random techniques were used. A questionnaire was the main instrument used for the collection of data for the study. Two similar sets of questionnaire containing 20 items were designed for two main groups of respondents, the TVET teachers and the students. Another questionnaire was specifically designed for technical institute graduates. The questionnaire included closed-ended items and used 5-porn Likert scale. The findings of the study revealed that lack of resources has led to cuts in the volume of training expected to be provided in the technical institutes. These cuts are hindrances to a pursuit of critical objective of providing training and subsequent that there is generally inadequacy in the provision of instructional material which leads to focusing more on theoretical teaching to trainees lacking proficiency in their chosen fields of specialization. It also revealed that there are inappropriate teaching methods used for practical teaching. As a result, the practical skill training is not closely related to the requirements of the world of work. Technical institute graduate lack the requisite skills for the job market so had few changes of gaining employment.

In a similar manner, Titus (2014) carried a study on development of entrepreneurial skills training modules for capacity building of carpentry and joinery craftsmen in South West Nigeria. Research and Development was used for the study. The population for the study was 318 respondents comprising of 101 carpentry and joinery teachers, 113 Business Education Lecturers and 104 craftsmen. There was no sampling because of the 
manageable size of the respondents. Two sets of questionnaire were used to collect data for the study, they include the needs assessment of questionnaire (NAQ) and structured questionnaire titled: Entrepreneurial skills training modules Questionnaire (ESTMQ). The outcome of the Need Assessment was used to develop the draft questionnaire for phase two of the study. The reliability test was carried in Kwara state outside the study area which yielded a reliability coefficient of $0.75,0.81,0.80,0.82$ and 0.79 for objectives contents, instructional methods, facilities and for evaluation techniques respectively. The data collected were analyzed using weighted mean and standard deviation, while Analysis of variance (ANOVA) was used to test the null hypotheses at 0.05 level of significance. All the skills contain in the questionnaire were all required for the development of entrepreneurial skills training modules.

\subsection{Purpose of the Study}

The general purpose of the study was to examine the perceptions of Adult and Nonformal learners in Nsukka LGA of Enugu state towards the prospects and purpose of globalisation and entrepreneurship. The specific purposes of the study are as follows:

i. To investigate the effects of Globalisation on Adult and Non-formal learners in Nsukka LGA of Enugu state.

ii. To investigate the effects of Entrepreneurship on Adult and Non-formal learners in Nsukka LGA of Enugu state.

iii. To examine the challenges to Adult and Non-formal learners in Nsukka LGA posed by the Globalisation agenda.

iv. To examine the challenges to Adult and Non-formal learners in Nsukka LGA posed by the Entrepreneurship agenda.

\subsection{Research Questions}

The following research questions were posed to guide the study:

i. What are the effects of Globalisation on Adult and Non-formal learners in Nsukka LGA of Enugu state?

ii. What are the effects of Entrepreneurship on Adult and Non-formal learners in Nsukka LGA of Enugu state?

iii. What are the challenges to Adult and Non-formal learners posed by the Globalisation agenda in Nsukka LGA of Enugu state?

iv. What are the challenges to Adult and Non-formal learners posed by the Entrepreneurship agenda in Nsukka LGA of Enugu state?

\section{Methodology}

The research design adopted for this study was the descriptive survey design. Descriptive survey design studies are mainly concerned with describing events as they are without any manipulations (Ali, 1996:59). This study aims at describing how Globalisation and Entrepreneurship affect Adult and Non-formal learners in Nsukka LGA of Enugu state. The research study covers Nsukka LGA of Enugu state. Nsukka has sixteen autonomous communities. Nsukka as a homogenous area has common features like religion and language. The population of the study is 360 adult and non-formal learners in Nsukka LGA of Enugu state. The population is distributed as follows: 
Table 1. Population and Sample Distribution

\begin{tabular}{clc}
\hline S/No & Adult and Non-formal Centres & Participants \\
\hline 1. & Adult education programme centre, Ugwuoye, Nsukka & 48 \\
2. & Adult education programme centre, Ihe-Owerre, Nsukka & 37 \\
3. & Adult education programme centre, Akutara, Obimo & 64 \\
4. & Adult education programme centre, Akpotoro, Obimo & 54 \\
5. & Adult education programme cnetre, Obinagu, Edem-Ani & 35 \\
6. & Adult education programme centre, Nru Union Primary & 54 \\
& School, Nsukka. & 68 \\
7. & Adult education programme centre, Odenigbo, Nsukka & $\mathbf{3 6 0}$ \\
\hline
\end{tabular}

Source: Adult education and non-formal unit, Nsukka LGA, /Enugu state.

The researchers used a total number of participants in the seven programme centres which gives a total number of 360 participants. The entire population of 360 participants was used because of the manageable number. The research instrument used for data collection was a well-structured questionnaire which was designed by the researchers. The questionnaire was organised on a four-point rating scale of Strongly Agree (SA), Agree (A), Disagree (D) and Strongly Disagree (SD). There are two parts in the instrument Part A sought to collect personal data such as the sex of the respondents, Part B which has eighteen items was arranged in four clusters to elicit information from participants on their knowledge about the effects of globalisation and entrepreneurship on adult and nonformal learners and also the challenges posed by the globalisation and entrepreneurship agenda to adult and non-formal learners.

Copies of the questionnaires were presented first to other colleagues and to experts in educational research for scrutiny and vetting. The instrument was further subjected to trial testing using participants who are involved in Adult and Non-formal education in Awka, Anambra state. Their copies were not used in the study. their responses were collated and analysed to determine the reliability of the instrument. Internal consistency and reliability were estimated using the Cronbach Alpha method for sections A and B. The coefficients were 0.58 for section A, 0.49 for section $\mathrm{B}$ and 0.63 for the overall instrument. The researchers administered 360 copies of the questionnaire to the respondents. At the end of the administration, 358 copies of the instrument were collected, accounting for $99.4 \%$ return rate. The essence of administering the instrument personally was to make clarifications on the items if the need arose. This reduced likely errors that could have occurred in the process of the respondents filling the responses to items in the questionnaire. The researchers used the mean score in analysing the data collected. The cut-off point for accepting an item is 2.50. Any item from 2.50 and above represents agreed, while the mean score of an item below 2.50 indicates that the respondents disagreed with the item.

\section{Results}

Research Question 1: What are effects of Globalisation on Adult and Non-formal learners? 


\section{Table 2. Mean Ratings (x) and the Standard Deviation (S) of the Effects of Globalisation on Adult and Non-formal Learners in Nsukka LGA of Enugu State}

\begin{tabular}{clccc}
\hline S/No & Effects of Globalisation on Adult and Non-formal learners & $\mathbf{X}$ & $\mathbf{S}$ & Interpretation \\
\hline 1. & $\begin{array}{l}\text { The basic human right to education has been breached by the } \\
\text { current globalisation trends. }\end{array}$ & 2.86 & 1.06 & Agree \\
2. & $\begin{array}{l}\text { The recent economic crisis had a negative impact on the } \\
\text { funding of the Adult and Non-formal educational system. }\end{array}$ & 3.14 & 1.11 & Agree \\
3. $\quad \begin{array}{l}\text { The dominance of Western crises had a negative impact on the } \\
\text { funding of the Adult and Non-formal educational system. }\end{array}$ & 3.19 & 1.31 & Agree \\
4. $\begin{array}{l}\text { The goal of Globalisation is to break down divisions between } \\
\text { academic and vocational skills. }\end{array}$ & 2.19 & 1.21 & Disagree \\
5. $\begin{array}{l}\text { Globalisation tries to improve the qualifications of the adult and } \\
\text { non-formal educators. }\end{array}$ & 2.53 & 1.24 & Agree \\
\hline
\end{tabular}

Table 2 showed that out of the five effects of Globalisation on Adult and Non-formal education, four was agreed on with mean ratings of 2.86, 3.14, 3.19 and 2.53. This implies that the Adult and Non-formal learners believe that the basic human right to education has been breached, the Adult and Non-formal education sector has been de-funded following the recent economic crises, the dominance of western values and knowledge has affected their learning conditions and globalisation has tried to improve the qualifications of the Adult and Non-formal educators. One was not agreed on as shown by the mean rating of 2.19. This implies that the goal of globalisation is not to break down divisions between academic and vocational skills.

Research Question 2: What are effects of Entrepreneurship on Adult and Non-formal learners?

\section{Table 3. Mean Ratings (x) and the Standard Deviation (S) of the effects of Entrepreneurship on Adult and Non-formal Learners in Nsukka LGA of Enugu State}

\begin{tabular}{clccc}
\hline S/No & $\begin{array}{l}\text { Effects of entrepreneurship on adult and non-formal } \\
\text { learners }\end{array}$ & $\mathbf{X}$ & $\mathbf{S}$ & Interpretation \\
\hline 6. & $\begin{array}{l}\text { Entrepreneurial skills help to reduce poverty in the developing } \\
\text { countries. }\end{array}$ & 2.9 & 1.08 & Agree \\
$7 . \quad \begin{array}{l}\text { Entrepreneurial education helps to increase the productive rate } \\
\text { of Adult and Non-formal learners. }\end{array}$ & 1.22 & Agree \\
8. & $\begin{array}{l}\text { Entrepreneurial programs are designed to prepare people for } \\
\text { work in information technology fields. }\end{array}$ & 1.01 & Disagree \\
9uality entrepreneurial education helps increase the number of & 3.4 & 1.31 & Agree \\
\hline
\end{tabular}

Table 3 revealed that out of the four effects of Entrepreneurship on Adult and Nonformal learners, three were agreed on by the respondents with mean ratings of 2.9, 3.2, 3.4. This implies that entrepreneurial skills help reduce the pressure of poverty on the learners, develop their productive rate and improve the rate of Adult and Non-formal learners in the society. One was not agreed as shown by the rating of 2.2. This implies that the learners believe that entrepreneurial programs are not designed to help people work in information technological skills.

Research Question 3: What challenges have Adult and Non-formal learners under the Globalisation Agenda? 
Table 3. Mean Ratings (x) and the Standard Deviation (S) of the Challenges Posed by the Globalisation Agenda to the Adult and Non-formal Learners

\begin{tabular}{cllll}
\hline S/No & $\begin{array}{l}\text { Challenges faced by adult and non-formal } \\
\text { learners under the Globalisation agenda }\end{array}$ & $\mathbf{X}$ & $\mathbf{S}$ & Interpretation \\
\hline 10. & $\begin{array}{l}\text { The globalisation agenda is critical to the } \\
\text { learning process of Adult and Non-formal } \\
\text { education. }\end{array}$ & 2.73 & 1.36 & Agree \\
11. $\begin{array}{l}\text { The curriculum reform under this agenda has a } \\
\text { negative impact on the learning conditions of } \\
\text { the Adult and Non-formal learners. }\end{array}$ & 2.18 & 1.21 & Disagree \\
12. $\begin{array}{l}\text { The curriculum reform under this agenda has a } \\
\text { positive impact on the educator/learner } \\
\text { conditions of Adult and Non-formal education. }\end{array}$ & 2.55 & 1.23 & Agree \\
13. $\begin{array}{l}\text { Adult and Non-formal learners perceive } \\
\text { globalisation as a way forward towards better } \\
\text { learning strategies. }\end{array}$ & 2.53 & 1.22 & Agree \\
14. $\begin{array}{l}\text { Instructors' development and retraining } \\
\text { improve the learning strategies of the Adult } \\
\text { and Non-formal learners. }\end{array}$ & 2.69 & 1.20 & Agree \\
\hline
\end{tabular}

Table 4 showed that of all the five challenges faced by Adult and Non-formal learners under the globalisation agenda, four were agreed on by the respondents with mean ratings of $2.73,2.55,2.53$ and 2.69 respectively. One was not agreed on by the respondents with a mean rating of 2.18. This implies that curriculum reform under the globalisation agenda has had a positive impact on the learning conditions of Adult and Non-formal learners.

Research Question 4: What are the challenges of Entrepreneurship to Adult and Nonformal learners?

\section{Table 5. Mean Ratings (x) and Standard Deviation (S) on the Challenges posed by Entrepreneurship to Adult and Non-formal Learners}

\begin{tabular}{clccl}
\hline S/No & $\begin{array}{l}\text { Challenges of entrepreneurship to adult } \\
\text { and non-formal learners }\end{array}$ & $\mathbf{X}$ & $\mathbf{S}$ & Interpretation \\
\hline 15. & $\begin{array}{l}\text { The low pressure of Adult and Non-formal } \\
\text { learners to entrepreneurship programmes } \\
\text { causes barriers to gaining entrepreneurial } \\
\text { skills. }\end{array}$ & 3.21 & 1.31 & Agree \\
16. & $\begin{array}{l}\text { Entrepreneurship as a strategy is not enough } \\
\text { to create jobs for Adults and Non-formal } \\
\text { learners. }\end{array}$ & 2.64 & 1.13 & Agree \\
17. & $\begin{array}{l}\text { Effective entrepreneurship education is } \\
\text { linked to people's economic and productive } \\
\text { activities. }\end{array}$ & 2.69 & 1.21 & Agree \\
18. & $\begin{array}{l}\text { Entrepreneurship education programmes } \\
\text { lack basic public and private funding. }\end{array}$ & 2.87 & 1.36 & Agree \\
\hline
\end{tabular}

Table 5 showed that of all the four challenges faced by adult and non-formal learners under the entrepreneurship agenda, all were agreed upon with the mean ratings of 3.21, $2.64,2.69,2.87$ respondents. The respondents believe that low exposure causes barriers to the gaining of entrepreneurship as a strategy is not enough to create jobs, effective entrepreneurship is liked to adult and non-formal learner's productive activities and entrepreneurship programme lack basic public and private funding. 


\section{Discussion}

The results of research question one shows that of the five identified effects of globalisation, the adult and non-formal learners agreed that the basic human right to education has been breached, the funding for their educational programmes has been cut off, the dominance of western values and knowledge has affected them and globalisation has tried to improve their qualification of their trainers. In a more depressing vein, Maurice Amutable in his account showed that Kenyan government in the 1960s and 1970s but they were asked to de-fund the sector as part of the provision of the structural readjustment policies by the International Monetary Fund (IMF) and the world bank and this affected the number of participants in the adult and non-formal programme (Walters, 1997). The adult and non-formal learners did not agree that globalisation tries to break down division between academic and vocational skills.

The results of research question two shows that of the four identified effects of Entrepreneurship, Adult and Non-formal learners agreed that Entrepreneurial skills help reduce poverty in developing countries, entrepreneurial education helps increase their productive rate, quality entrepreneurial education helps increase the number of learners. The fundamental role that entrepreneurial skills play in the reduction of poverty was supported by Pieck Enrique (2000), when he said that the development of entrepreneurial skills are traditionally geared towards survival and assistance and the combination of effective programmes in poverty areas through work-related adult and non-formal educational programmes. The adult and non-formal learners believe that entrepreneurial programmes are not designed to help the learners work in information technology fields.

The results of research question three shows that of the five identified challenges posed by globalisation, adult and non-formal learners agreed that the agenda of globalisation is critical to the learning process of adult and non-formal learners, the curriculum reform has had a positive impact on their learning conditions, globalisation is perceived as a way forward towards the attainment of better learning strategies and instructors' development and retraining improves the learning strategies of adult and non-formal learners. In the heart of the globalisation agenda is the revival of adult and non-formal education programmes which is being reformed as a tool for sustained and broad-based development in all poor regions of the world, Africa and Nigeria in particular (UNESCO, 2006). More fruitful is the coming to grips with the novel ways globalisation tries to orient Adult and Non-formal learners to a culture of peace and socially inclusive development and to a sustainable community of people and cultures worldwide (Bekeman, 2002:153).

The results of research question four show that of four identified challenges posed by entrepreneurship, all were agreed on by the respondents. This implies that low exposure of learners to entrepreneurship programmes causes barriers to gaining entrepreneurial skills, entrepreneurship as a strategy is not enough to create jobs and its programmes lack basic public and private funding. These challenges are in line with Wilson (2009) who believes that Entrepreneurship education can help promote an entrepreneurial and innovative culture by changing the mindsets of and providing the necessary skills to Adult and Non-formal learners. She also believes that to develop the field of entrepreneurship education which is still relatively young, public and private support which has been seen to be lacking, be improved and embedded in a sustainable manner in adult and non-formal education centres. Overall, the Adult and non-formal learners do not agree that effective entrepreneurship education is linked to the productive and economic activities of a set of people including the Adults and Non-formal learners in Nsukka ALGA of Enugu state.

\section{Conclusion}

The government at all levels should ensure that entrepreneurship education meets the basic funding requirements in order to achieve the objectives posed by the globalisation 
agenda. Curriculum reform in Adult and Non-formal education should embed entrepreneurship in education as Entrepreneurship in education as Entrepreneurship has been seen as one of the most important steps to building an innovative culture and creating a new wave of entrepreneurs, entrepreneurial individuals and organisations. The government at all levels should allow concerted international and private organisations assist with their aids to enable adult and non-formal learners learn without borrowing as this may at the end jeopardise their quest for reading without pains and fear of not being able to pay back. The government both at national and local levels should make sure that entrepreneurship education is used to reduce the high rate of unemployment in both urban and rural areas of Nigeria, by equipping adults and non-formal learners with the knowledge and skills for setting up and running small businesses effectively. Instead of running after half-based certificates that at the end only keeps one unemployed. The government both at national and local levels should ensure that adult and non-formal learners not only overcome dependency and hopelessness but stimulate the emergence of an enterprising culture that values creativity, self-efficacy, self-employment and selfsufficiency.

\section{References}

[1] J. Cruickshank, "The role of advocacy: A critical issue in Canadian University extension work", Studies in the Education of Adults, vol. 25, no. 2, (1993), pp. 172-183.

[2] P. J. Denning, "Business designs for the new university", Educom Review, (1997), pp. 21-30.

[3] J. Newson, "The corporate linked university: from social project to market force", Canadian Journal of Communication, vol. 23, no. 10, (1998), pp. 107-124.

[4] E. A. Adam, "In pursuit of a new enterprise and entrepreneurship paradigm for learning", International Journal of Management, vol. 2, no. 3, (2011), pp. 30-35.

[5] K. O. Jibodu and A. G. Phiri, "Updating Polytechnic Curriculum to suit work functions in employment", A Journal of Technical Education \& Training, (1990), pp. 26-32.

[6] A. E. Uzoagulu, "Toward on Effective Equipment Management in Schools for Economic and Technical Self-reliance", Nigerian Vocational Journal, no. 1, (1993), pp. 25.

[7] A. A. Enete, T. A. Amusa and N. M. Eze, "Entrepreneurial Competency Required by Students of School of Agriculture in Southwestern Nigeria for Processing Cocoyam into Flour chips for Employment on Graduation", Nigerian Vocational Journal, vol. 13. no. 1, (2009), pp. 1-11.

[8] A. Kaidese, "An Assessment of the level of Entrepreneurial Aspiration of Ogun State Tertiary Institutions Students", Africa Journal of Cross Cultural Psychology and Sport Facilitation, no. 10, (2008), pp. 192-198.

[9] S. O. Olaitan, S. O. Eze and E. Ogbonnaya, "Entrepreneurial competencies Required by Secondary Schools Graduate for Entering into oil palm processing Enterprise in South Eastern States of Nigeria", Nigerian Vocational Journal, vol. 13, no. 1, (2009), pp. 70-73.

[10] K. K. Obiyai and N. A. Ezubo, "Development of Entrepreneurship Skills Training Module on Fish Breeding and Hatching Occupation", Asian Journal of Agricultural Science, vol. 2, no. 2, (2011), pp. 111-114.

[11] A. Ali, "Fundamental of Research Education", Meks Publisher (Nigeria), Awka, Anambra State, (1996).

[12] L. Bekemans, "Introductory report - Globalisation and Solidarity: Europe's duty in intercultural dialogue", European Commission, UK, (2002).

[13] P. Frieires, "Pedagogy of the Oppressed", The Continuum Publishing Company, New York, (1996).

[14] M. Lozono, "Monitoring the World Economy", Organisation for Economic Cooperation and Development, Paris, (2002).

[15] J. Stiglitz, "The Challenge of African Development", Oxford University Press, (2002).

[16] UNESCO, "Literacy for Life' Global Monitoring Report", UNESCO, Geneva, (2006).

[17] S. Walters, "Globalisation, Adult Education and Training: Impacts and Issues", Zed Books, London (1997).

[18] M. Welton, "In Defence of the Civil Society: Canadian Adult Education in Neo-Conservative Times, ICAE, Toronto, (1997).

[19] K. E. Wilson, "Challenges facing entrepreneurship education", European Foundation for Entrepreneurship Research, (2009).

[20] W. J. Baumol, "The Free-Market Innovation Machine: Analysing the Growth Miracle of Capitalism", Princeton University Press, Princeton, New Jersey, (2002).

[21] A. N. Alio, "Strategies for Enhancing the competencies of Electronics craftsmen in the informal sector of the Economy of Enugu State", Ph.D Theses, University of Nigeria, Nsukka, (2006). 
[22] I. Oko, "Entrepreneurial Competencies required by Technicians for success in small scale Automobile Maintenance Industry in Benue State", M.Ed. Thesis, University of Nigeria, Nsukka, (2011).

[23] O. O. Titus, "Development of Entrepreneurial Skills Training Modules for Capacity Building of Carpentry and Joinery Craftsmen in South West, Nigeria", Ph.D Thesis, University of Nigeria, Nsukka, (2014).

[24] D. B. Johnstone, A. Alka and E. William, "The financing and management of higher education: A status report on worldwide reforms", UNESCO world conference on higher education, Paris, (1998) October 5-9.

[25] UNESCO, "UNESCO Institute for education, the Hamburg declaration", The Agenda for the Future. Fifth International Conference on Adult Education, (1997). 
International Journal of $u$ - and e- Service, Science and Technology

Vol. 11, No.3 (2018) 